JOANNA WOJNICKA

\title{
Epitafium dla taty, czyli Śmierć pięknych saren Oty Pavla i Karela Kachyni
}

Ota Pavel był niezwykłym pisarzem, ale też człowiekiem dramatycznej biografii. Urodził się w 1930 r. w Pradze jako Otto Popper. Był najmłodszym z trzech braci wychowywanych w mieszanej żydowsko-czeskiej rodzinie. Jego ojciec, Leo Popper, to postać jakby wyjęta z kart popularnej literatury przygodowej. Po pierwszej wojnie światowej (w której jako żołnierz brał udział) zaciągnął się do Legii Cudzoziemskiej. Odbył służbę w Maroku, skąd uciekł. Schwytany przez Berberów, uszedł z życiem i przez jakiś czas przebywał w Maladze, zarabiając czytaniem gazet miejscowym analfabetom. Z Malagi również musiał uciekać. Po pewnym czasie przez Stambuł dotarł do Europy. Po ślubie z pochodzącą z niezamożnej rodziny Czeszką porzucił - przynajmniej w teorii - awanturnicze życie. Został komiwojażerem, sprzedawcą odkurzaczy firmy Elektrolux. Kiedy w 1939 r. po zajęciu Czechosłowacji przez Hitlera został utworzony Protektorat Czech i Moraw, dzieci z mieszanych małżeństw, zgodnie z obowiązującymi na jego terenie ustawami rasowymi, wysyłano do obozów koncentracyjnych. Tak do obozów trafili dwaj starsi bracia Ottona. Najpierw do Terezina, potem Oświęcimia i Mauthausen. Do obozu zabrano także ojca. To, że wszyscy trzej przeżyli wojnę, zakrawa na cud. Po wojnie Ota imał się różnych zajęć, aby wreszcie otrzymać posadę komentatora sportowego najpierw w czechosłowackim radiu, później w jednej z gazet sportowych. Jako komentator wyjeżdżał za granicę i właśnie za granica, a dokładnie w Austrii, w Innsbrucku, podczas zimowych igrzysk olimpijskich 1964 r. wydarzyła się tragedia.

Dostałem pomieszania zmysłów na zimowej olimpiadzie w Innsbrucku. Mózg mi się zaćmił, jak gdyby spłynęła mgła z Alp. Zobaczyłem pewnego pana jako diabła w całej okazałości, miał rogi, kopyta, sierść i wiekowe spróchniałe zęby. Potem poszedłem w górę nad Innsbruckiem, żeby podpalić zabudowania wiejskie. Byłem przekonany, 
że taka jasność rozproszy mgłę. Wyprowadziłem już krowy i ogiery ze stajni, żeby nie spłonęły, kiedy dopadła mnie austriacka policja. Założyli mi kajdanki i poprowadzili w dolinę. Wymyślałem im, zdarłem z nóg buty i szedłem po śniegu boso jako Chrystus, którego prowadzą na krzyż $\dot{1}^{1}$

Co takiego wydarzyło się w Innsbrucku? Podobno atak choroby psychicznej przyszedł po tym, jak Pavel usłyszał okrzyki niemieckich kibiców. Język niemiecki przywołał traumatyczne wspomnienia z czasów wojny. Jednoznacznych przyczyn - zapewne - określić nie sposób, ale następne lata Pavla są wypełnione pobytami w szpitalach psychiatrycznych, depresjami, próbami samobójczymi. Także pisaniem, które miało być dla niego formą terapii. Oczywiście pisał już jako dziennikarz sportowy. W 1962 r. stworzył nawet (razem z Františkiem Kožikiem) scenariusz do filmu Ostatni etap (1962) wyreżyserowanego przez Miroslava Ondráčka. Jednakże prawdziwe pisarstwo, to, które przyniosło mu miejsce $\mathrm{w}$ historii czeskiej literatury, mocno związane jest z chorobą. W $1971 \mathrm{r}$. ukazała się Śmierć pięknych saren, a w 1974 r. - już po śmierci autora, który kilka miesięcy przed publikacją, w roku 1973, zmarł na serce - Jak spotkałem się z rybami. Razem z wydaną już na początku lat 90 . książką Jak tata przemierzał Afrykę - jej tekst znaleziono w papierach zmarłego twórcy - łączą się one w autobiograficzny cykl. Każda z wymienionych książek składa się z krótkich opowiadań, w których Pavel opowiada o swoim życiu, głównie jednak o dzieciństwie spędzonym w cieniu nietuzinkowego ojca, a także - a może przede wszystkim - o dzieciństwie przeżywanym na tle historii własnego kraju.

Lektura tych tekstów przenosi nas w niezwykły świat i pozwala również obcować z niezwykłym językiem pisarza. Śmierć pięknych saren rozpoczyna dedykacja Mamusi, która miała za męża mojego tatusia. Dedykacja dziecka. Pavel jakby celowo używał słów „mamusia”, „tatuś". Jego narracja jest bowiem na poły dziecięca. W konsekwencji wygląda to tak, jak gdyby narrator opisywał świat, na który patrzy dziecko - dziecko naiwne, a jednocześnie potrafiące wiele dostrzec. Pavel nękany pobytami w szpitalach i powracającymi atakami choroby zaczął pisać po to, by uporać się z traumą przeszłości, a jednocześnie uporządkować swoje wspomnienia, które być może warunkowały jego stan psychiczny. Ta pozorna naiwność, podszywanie się pod dziecko, kreacja świata mająca czasami cechy (ale tylko pozornie) infantylnej zabawy, być może były konwencją wyni-

1 Ota Pavel, Jak spotkałem się z rybami, tłum. Józef Waczków, [w:] tenże, Śmierć pięknych saren, Wyd. „Śląsk”, Katowice 1988, s. 203. 
kającą z owej terapii przez sztukę. Jednak w przypadku Pavla mamy do czynienia z pisarstwem znakomitym i dojrzałym. Autor nie był przecież debiutantem, pracował jako dziennikarz i jego warsztat był już wypracowany. Dlatego ów na poły dziecinny język trzeba traktować raczej jako metodę kreacji świata, dzięki której osiąga on ów niezwykły efekt prostoty i czułości, ukrywających ogromny ładunek dramatyzmu.

Najważniejszą postacią literackiego świata Oty Pavla jest tatuś - figura z krwi i kości, a równocześnie jakby mityczna: bohater dziecięcych snów. Przygody ojca, jego praca, szalone pomysły, sukcesy i porażki opisuje Pavel prosto, z humorem, czasami nieco ironicznie - tu ujawnia się ów dystans dorosłego człowieka dostrzegającego sprawy, jakich nie rozumie dziecko. Z tych opisów wyłania obraz rodziny żyjącej najpierw w przededniu nadciągającej katastrofy, a potem wśród jej skutków.

W 1986 r. Śmierć pięknych saren przeniósł na ekran Karel Kachynia. Nie było to pierwsze spotkanie reżysera z prozą Oty Pavla. W 1979 r. zrealizował on już telewizyjny film Złote wegorze na podstawie fragmentu książki Jak spotkałem się z rybami. Kachynia należał do mistrzów czeskiej Nowej Fali, wywodził się jednak z pokolenia starszego od Formana i Menzla (urodził się w 1924 r.), a zadebiutował jeszcze w latach 50. Zaczął od filmów dokumentalnych, które z początku realizował z Vojtěchem Jasným. Późniejsza, a właściwie dojrzalsza, bo ta pochodząca z lat 60., twórczość Kachyni łączy się z osobą pisarza Jana Procházki, który, podobnie jak Kachynia, rozpoczął współpracę z filmowcami w latach 50. Początkowo pisał on scenariusze dla Josefa Macha, potem - można powiedzieć na stałe - związał się Kachynią. W drugiej połowie lat 60 . nakręcili razem kilka filmów, z których największą - i kontrowersyjną - sławę zyskał pewnie Wóz do Wiednia (1966). Tę niezwykłą, okrutną opowieść z czasów drugiej wojny światowej o kobiecie, która najpierw chce pomścić męża, a potem zakochuje w austriackim żołnierzu, którego wcześniej chciała zabić, oskarżano o antyczeski wydźwięk. Duet Kachynia-Jasný istniał do końca lat 60., współtworząc jakość nowego kina razem z młodszymi debiutantami. Skończył się wraz z przedwczesną śmiercią Procházki w roku 1971, którego aktywność storpedowano już po wkroczeniu wojsk Układu Warszawskiego do Pragi. Procházka stał się wtedy bohaterem skandalu politycznego. A był przecież znanym pisarzem, członkiem partii, wiceprzewodniczącym Czechosłowackiego Związku Literatów w latach 1968-1969. W roku 1969 został wmanipulowany w sytuację, która całkowicie przekreśliła jego karierę, ba, całe życie. Służba bezpieczeństwa nagrała i w odpowiedni sposób przemontowała prywatne rozmowy Procházki, które potem wyemitowano 
w telewizji jako część poświęconego mu filmu dokumentalnego. Te rozmowy były prywatne, ale poświęcone tematom politycznym² ${ }^{2}$. Procházka natychmiast stał się persona non grata. Zdążył jednak napisać znakomity scenariusz, a Kachynia nakręcić na tej podstawie film zatytułowany Ucho - poruszającą opowieść o inwigilacji, strachu i konformizmie. Film powstał w 1969 r., ale szybko został zatrzymany. Czekał na premierę dwadzieścia lat (do roku 1990). Sam reżyser został zmuszony do wygłoszenia upokarzającej samokrytyki i zanegowania dotychczasowej współpracy z pisarzem. Mogła ona bowiem poważnie storpedować jego karierę. Tak się zresztą do pewnego stopnia stało - w latach 70. kręcił Kachynia głównie filmy dla dzieci. Ów fakt, zanegowanie wieloletniej współpracy z Procházką, przypomina się czasem jako wydarzenie, które położyło się cieniem na biografii reżysera, jednak Mariusz Szczygieł, który dla polskiego czytelnika zrelacjonował tę dawną sprawę, przypomina, że w wywiadach, których Kachynia udzielił, nazwisko Procházki nie pojawiło się bezpośrednio, a ukazały się one dwa miesiące po śmierci pisarza. Na dociekliwe pytania dziennikarza reżyser odpowiadał: „Byłoby łatwo tutaj, na papierze, wyprzeć się wszystkiego, co wczorajsze, zaś płomiennie dopisać się do tego wszystkiego, co dzisiejsze" ${ }^{\prime \prime 3}$. Nie zrezygnował z tematów, które go prawdziwie zajmowały, mimo że nie miał już tych możliwości, co w latach 60. Nie zrezygnował też z nietuzinkowych współpracowników.

Scenariusz do Śmierci pięknych saren - jak i do Złotych węgorzy - napisał Kachynia razem z Dušanem Hamšíkiem. To kolejna niezwykła postać w otoczeniu reżysera. Urodzony w 1930 r. Hamšík był dziennikarzem i filozofem o bogatym dorobku. W 1967 r. został redaktorem literackiego pisma „Literárni listy”, które prędko stało się jednym z ważniejszych periodyków tworzących elementy niezależnej kultury. Hamšík pracował w nim do roku 1968. W latach 60. pisał reportaże, choć jego głównym obszarem zainteresowań był nazizm i III Rzesza, którym poświęcił wiele lat badań. Pisywał książki z pogranicza eseju i literatury faktu (jedna z nich, Bomba dla Heydricha, napisana wraz z Jiřím Pražákiem i poświęcona słynnemu zamachowi na Reinharda Heydricha, protektora Czech i Moraw, została już w latach 60. przetłumaczona na język polski). Owocem tych zainteresowań była też praca, którą Hamšik wydał początkowo w samiz-

2 Por. Peter Hames, Czechosłowacka Nowa Fala, tłum. Justyna Burzyńska, Ewa Ciszewska, Karol Chojnowski, Irena Hansz, Joanna Matyskieła, Grażyna Świętochowska, słowo/obraz terytoria, Gdańsk 2009, s. 93-105. O okolicznościach zatrzymania kariery Procházki pisze Mariusz Szczygieł w książce Gottland; por. Mariusz Szczygieł, Gottland, Wyd. Czarne, Wołowiec 2006, s. 105-129.

3 Mariusz Szczygiel, dz. cyt., s. 124. 
dacie (w 1974 r.). Poświęcił ją Heinrichowi Himmlerowi. Nosiła tytuł Życie $i$ dzieło Heinricha Himmlera i stała się podstawą innej pracy, opublikowanej oficjalnie w latach 80. - Drugi człowiek w Trzeciej Rzeszy (wydanie polskie w roku 1991), którą Hamšík zadedykował pamięci... Oty Pavla. Współpraca Kachyni i Hamšíka nie była więc przypadkowa. Pisarz nie figuruje wprawdzie w czołówce Śmierci pięknych saren, ale to, że jego współpraca z Kachynią była istotna dla filmu jest bezsporne. Zresztą współpracował z nim już przy realizacji filmu Złote węgorze. Napisał też dla Kachyni kilka innych scenariuszy: Oznamuje se láskám vašim (Do wiadomości waszych ukochanych) - film powstał w 1988 r., Pociag dzieciństwa i nadziei - serial, który Kachynia skończył realizować w 1985 r., a który cztery lata czekał na emisję. Scenariusz tego serialu powstał na podstawie powieści Věry Sládkovej. Jej akcja rozgrywała się tuż przed wojną w niewielkim miasteczku zamieszkanym przez ludność niemiecką i czeską. Zajęcie przez nazistów Czechosłowacji dramatycznie zmienia relację między mieszkańcami. Wszystkie te filmy, także Śmierć pięknych saren, powstały już po śmierci Hamšíka, który w roku 1985 popełnił samobójstwo. Wbrew temu więc, co pisze Peter Hames, że Kachynia po klęsce Praskiej Wiosny i zaostrzonej cenzurze „pracował wyłącznie przy filmach dla dzieci”"4 (co po części jest prawdą, ale dotyczyło lat 70.), dorobek reżysera okazał się bardziej różnorodny, zaś temat wojny wracał w nim wielokrotnie.

Kiedy zestawia się dorobek czechosłowackiego kina opowiadającego o wojnie z kinematografią innych krajów przez tę wojnę doświadczonych (na przykład Polski), uderza - i tak się zwykło to charakteryzować - pewna prostota podejmowanych tematów, prywatność zamiast wielkiej historii, czasem humor zamiast tragedii. Stwierdzenie bardzo uproszczone. Zarówno kino, jak i czeska literatura dostarczają wystarczająco wiele dowodów na to, że obraz wojny bywa w nich przerażający, choć często chowany w masce groteski. Skłonność do wyrafinowanego sadyzmu mieszanego z ironią i kryjącego się w zakamarkach codzienności pojawiła się już w czeskiej literaturze modernistycznej, gdzie ekspresjonizm i surrealizm rozwijały się nad podziw dobrze. Doświadczenie hitlerowskich rządów w kraju o tak licznej mniejszości niemieckiej, bogatej żydowskiej kulturze, a przede wszystkim tak niejednoznacznej postawie politycznej, której rzekomy realizm zbyt chętnie przeciwstawiamy - zwłaszcza w Polsce, wartościując go przy tym pozytywnie - straceńczej brawurze, okazał się intrygującym tematem. Protektorat Czech i Moraw był satelickim tworem III Rzeszy, w kraju działały organizacje faszystowskie,

4 Peter Hames, dz. cyt., s. 307. 
istniała oficjalna Partia Narodowo-Socjalistyczna (zwana partią Zielonej Swastyki), faszystowskie brygady funkcjonujące już w latach 30., takie jak Vlajka, albo współpracujące z Niemcami organizacje paramilitarne, jak Gwardie Światopełkowe. Był też ruch oporu (i rząd emigracyjny), ale rzeczywistość w kraju była daleka od heroicznej walki. Właśnie owo „zwykłe” życie w cieniu wojny opisuje Pavel. „Zwykłość” nie była jednak do pozazdroszczenia, skoro doprowadziła pisarza do szaleństwa. Inny znany autor zapuszczający się $\mathrm{w}$ te dwuznaczne rejony, późny debiutant lat 60 ., Ladislav Fuks - homoseksualista ze skłonnością do młodych przestępców, $\mathrm{w}$ latach 70. stał się serwilistycznym literatem chwalącym uroki socjalistycznej ojczyzny i podobnie jak Pavel otarł się o szpital psychiatryczny. Te tragiczne biografie (ów rys potwierdza też biografia Dušana Hamšíka) i znakomite książki dowodzą fałszu obiegowych stwierdzeń o „pogodnym, czeskim spojrzeniu na wojnę". Z drugiej jednak strony trudno od nich uciec, oglądając na przykład film Karela Kachyni. Pozornie jest to bowiem opowiastka o niebanalnej rodzinie, której historia zgotowała tragiczną niespodziankę.

Książkę Oty Pavla rozpoczyna historia z karpiami. Ojciec Leo postanawia "okazyjnie" kupić staw i hodować w nim karpie. Nie podziela marzeń swojej żony o podróży do Włoch.

Mój tatuś miat bowiem całkiem inne zmartwienia - pisze narrator. - W centrum jego zainte-
resowań znajdowały się: handel i ryby. I w jednym, i w drugim wyróżniał się wprost nadzwy-
czajnie, rybom dawał pierwszeństwo ku wiecznej szkodzie naszej rodziny, a także szwedzkiej
firmy Elektrolux, w której pracował jako agent-komiwojażer sprzedający lodówki i odkurzacze.
Często po prostu zbaczał z szlaku podróży handlowej i znajdowano go najczéściej nad Bie-
rounka, gdzie wraz ze swoim najlepszym przyjacielem, przewoźnikiem Karolem Proszkiem
tapał szczupaki na okonki ${ }^{5}$.

Pomysł kupna karpiego stawu miał przynieść rodzinie fortunę. Niestety, populacja ryb nie przekroczyła jednej sztuki, zresztą tej samej, która żyła w stawie jeszcze przed jego kupnem. Cudowny interes okazał się więc klapą, a uroczysty połów karpi całkowitą klęską. Tak powoli poznajemy historię całej rodziny, przede wszystkim zaś historię Leo Poppera lekkomyślnego obieżyświata i niepoprawnego romantyka. Narrator snuje opowieść jakby relacjonował wydarzenia rozgrywające się w przeszłości, które jednak wciąż budzą żywe emocje. Jest ich uczestnikiem, patrzy na świat, na swojego ojca, oczami dziecka, lecz my, przyjmując tę konwencję,

5 Ota Pavel, Śmierć pięknych saren, tłum. Andrzej Piotrowski, [w:] tenże, Śmierć pięknych saren..., s. 18. 
wiemy równocześnie, że narrator nie jest dzieckiem. Rozumie ten świat, potrafi go skomentować i zanalizować, tylko udaje małego obserwatora. Zabieg ten osiąga mistrzostwo, pozwalając na konstrukcję świata przy pomocy prostych środków. Kryją one ostrość, która ujawnia się w odpowiednim momencie. Kiedy narrator opisuje pobyt w chałupie przyjaciela rodziny, przewoźnika Karola Proszka, w pewnym momencie powiada: W chałupie przewoźnika Karola Proszka - miał taki sam wasik jak Adolf Hitler - znaleźliśmy schronienie na długie lata ${ }^{6}$. Jedno nazwisko zmienia całą historię. I nagle wszystko się skończyło, bo przyszedł były kapral Adolf Hitler, który miat pod nosem wasik jak mój ukochany wuj Karol Proszek7. Nic więcej, jedno krótkie zdanie.

Karol Kowarzyk, byty szewc głuchy jak dwa pnie, w austriackiej czapce na głowie $i$ w wyświechtanych łapciach. Miał czerwony bębenek i niebieskie pałeczki, a kiedy skończył bębnić, żebrat od nas chtopaków: Daj mi koronę [...].

A kiedy przyszedt Adolf Hitler, pan Kowarzyk zabębnit i ogłosit:

- Podaje się do wiadomości, że w tym kraju powstał Protektorat Czech i Moraw, Protektorat Böhmen i Mähren ${ }^{8}$.

Wtedy to Loe Popper i jego rodzina stali się obywatelami drugiej kategorii: Żydami, pół-Żydami, ćwierć-Żydami - jak podaje narrator. Opowieść toczy się pomiędzy zwykłymi, domowymi wydarzeniami a planem historycznym. Na pierwszym planie są te wydarzenia zwykłe. Musi tak być, bo opowieść snuje quasi-dziecięcy narrator, a przynajmniej ktoś, kto rekonstruuje dziecięcą wrażliwość. A dziecko nie pamięta wydarzeń wielkich, pamięta te małe, które bywają ich pochodną.

W trzecim roku wojny moi bracia Hugo i Jurek otrzymali wezwania do obozu koncentracyjnego.

- Ci chłopcy musza się przed odjazdem najeść - powiedziat wówczas tatuś. - I to mięsa. Przywioze jakieś ryby9.

W tym momencie opowieść o beztroskim ojcu-komiwojażerze, o ekscentryku i pięknoduchu, zamienia się w opowieść o ojcu-bohaterze, człowieku, który walczy z upodlającą sytuacją człowieka bez żadnych praw

\footnotetext{
Tamże, s. 46.

7 Tamże, s. 50.

8 Tamże.

9 Tamże.
} 
w państwie rządzonym przez nazistów. Walczy o swoje dzieci, o swoją rodzinę. Robi to jak potrafi najlepiej - fortelem, przebiegłością, nawet niemądrym żartem, robi to jednak skutecznie. Tatuś opuścit nasz dom w Busztegradzie - oznaczony numerem pięćdziesiatym czwartym - bez gwiazdy, odprut ją $i$ włożył do kieszeni, załadował na rower plecak, worki, a także składany basenik na węgorze ${ }^{10}$. Historia zdobywania mięsa dla chłopców, potem kradzieży karpi ze stawu zarekwirowanego przez Niemców jest popisem determinacji i sprytu. Leo Popper to człowiek, dla którego kłopoty są rodzajem dziwnej motywacji. Szuka najdziwniejszych sposobów ich pokonania. Są nawet jak ekscentryczna przygoda. Jak służba w Legii Cudzoziemskiej, a potem ucieczka z Afryki. Albo jak uzyskanie zgody sławnego malarza na sportretowanie pani Irmy - pięknej żony właściciela przedsiębiorstwa, w którym Leo Popper rozprowadzał odkurzacze.

Jedna z podstawowych różnic między książką Pavla a filmem Kachyni zawiera się w sposobie narracji. Reżyser rezygnuje z quasi-dziecięcej perspektywy subiektywnej, choć zdarzają się fragmenty, w których głos z off-u sugeruje istnienie konkretnego narratora komentującego wydarzenia z perspektywy wielu lat. Nie próbuje konstruować świata przy pomocy środków odtwarzających perspektywę dziecięcą. Wręcz przeciwnie. Żadne z dzieci nie jest - mówiąc językiem teorii - dyspozytorem spojrzenia. Czy ktoś nim jest? Czasami twórcy proponują zabiegi, które sugeruja, jakoby obraz świata, a może nawet cała opowieść prezentowana była z perspektywy ojca. Na przykład pierwsze ujęcie filmu. Oglądamy wakacyjną scenkę. Trzech chłopców z ojcem łowi nad rzeką ryby. W pewnej chwili mężczyzna podnosi do oczu lornetkę. Obserwuje stado saren. Co za wdzięk - mówi ${ }^{11}$. Oczy prawie ludzkie. Nawet piękniejsze. Nagle dostrzega biegnącego w stronę stada psa, wielkiego owczarka niemieckiego. Przecież to Holan - mężczyzna wydaje się rozpoznawać psa. Pies zaczyna biec w kierunku stada. Holan, stój. Nie rusz. Sarny uciekają, ale pies nie daje za wygraną, biegnie jak na polowanie. Holan to pies wuja Proszka, który - o czym dowiadujemy się i z powieści, i z filmu - rzeczywiście poluje na sarny. Przewoźnik Proszek ma żyłkę kłusownika. Filmowy tatuś zarzuca mu okrucieństwo. On sam jest miłośnikiem tych zwierząt, nie jada sarniny (w powieści nie jest to podkreślone).

W literackiej wersji epizod ten znajduje się w połowie tekstu. Wcześniej poznajemy sukcesy taty jako sprzedawcy firmy Elektrolux. W filmie jest odwrotnie. Najpierw epizod z sarnami, a potem opowieść o odkurza-

\footnotetext{
10 Tamże, s. 51.

11 Wszystkie cytaty pochodzą ze ścieżki dźwiękowej filmu.
} 
czach i fascynacji piękną panią Irmą. Umieszczenie epizodu z sarnami na początku filmu jest oczywiście zabiegiem celowym i ma znaczenie metaforyczne, choć z początku widzowie tego nie rozpoznają. Do pewnego momentu w ogóle nie wiedzą, o czym w istocie jest ten film, bo jego prawdziwy sens wyłania się powoli.

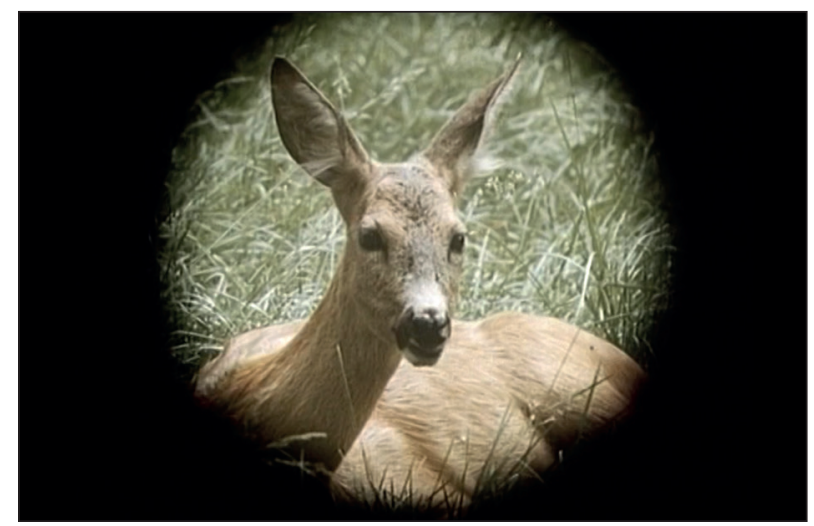

Fot. 8. Śmierć pięknych saren (1986, reż. Karel Kachynia) Jedna z saren obserwowanych przez tatusia

Na kępie nad rzeka pięło się w górę zbocze i było to zbocze niezwykłe: nie leżał tu ani jeden kamień, jakich mnóstwo bywa na takim stoku, ale na polankach pomiędzy potężnymi dębami rosła soczysta miękka murawa; tu przychodziła zwierzyna paść się, tędy biegła do wodopoju. Wtaściwie był to piękny ogród czy też park zamkowy, ale tak naprawdę byt to ogród śmierci, można tam było umieścić napis „śmierć pięknych saren" ${ }^{12}$

- pisze Ota Pavel w powieści. Skojarzenie myśliwskie jest tyleż okrutne, co trafne. Jakkolwiek pseudo-hinduistyczny wegetarianizm należał do światopoglądu nazistów (na przykład Hitlera), to polowania były namiętnością niektórych niemieckich przywódców. Tytuł Wielkiego Łowczego III Rzeszy przysługiwał marszałkowi Göringowi (skądinąd twórcy nowoczesnego prawa łowieckiego, którego humanitaryzmu i nowatorstwa zazdrościły podobno Niemcom inne państwa). Hiszpańska historyk Rosa Sala Rose zaważa trafnie:

Dlatego tym bardziej paradoksalne i zdumiewające jest to, że wysocy urzędnicy nazistowscy, wielbiciele zwierząt, mogli być tak okrutni wobec ludzi, których uważali za rasowo niższych. W 1945 roku Himmler twierdził z dumą, że „my, Niemcy, jesteśmy

12 Ota Pavel, Śmierć pięknych saren..., s. 48. 
jedynym narodem, który zachowuje się przyzwoicie wobec zwierząt", i dodawał, że „zachowamy się równie przyzwoicie wobec zwierząt ludzkich (chodziło o Czeszki i Rosjanki), lecz byłoby zbrodnią przeciwko naszej krwi starać się oszczędzać ich krew lub dostarczać im jakiekolwiek powody do życia"13.

Okrutne zestawienie, które autorzy filmu podkreślają jeszcze w zakończeniu, w scenie, kiedy starsi bracia Oty wyruszają do obozu. Ostatnie ujęcia filmu są właściwie kopią pierwszych. Hugo i Jurek idą w grupie ludzi przeznaczonych do transportu. Niosą za duże walizki, na kurtkach mają naszyte gwiazdy Dawida. Ojciec spogląda za nimi, stojąc w oknie. Podnosi do oczu lornetkę. Patrzy na nich tak, jak wcześniej obserwował sarny. Dwaj mali chłopcy widziani przez szkła lornetki zamieniają się w końcu w ujęcia saren - młodziutkich i pięknych. Takich samych, jakie pasły się w „ogrodzie śmierci” nad rzeką.

Tym sposobem początkowe ujęcia zyskują dopełnienie, a cała historia - właściwe jej rozwiązanie. Przejmującym dopełnieniem tych wydarzeń, jest fakt, że ojciec - aby zdobyć dla chłopców mięso - robi rzecz, którą się tak wcześniej brzydził: poluje na sarny. Polowanie nie jest dozwolone dla "gorszych" mieszkańców Protektoratu Czech i Moraw. Na tym terenie obowiązuje prawo łowieckie Göringa. Ale ojciec musi to zrobić - ryby nie biorą, a chłopcy potrzebują mięsa.

Obecne $\mathrm{w}$ powieści fakty historyczne $\mathrm{w}$ filmie pojawiają się mimochodem. Są jednak na tyle ważne, że nie można ich pominąć. Kiedy ojciec przyjeżdża do wuja Proszka z prośbą o pomoc, ten podczas powitania mówi mu: Nie zatrzymywali cię? Zabili Heydricha. O co chodzi? O zamach, którego na Reinharda Heydricha dokonali czescy i słowaccy cichociemni. Ten zamach miał miejsce 27 maja 1942 r. Heydrich zmarł kilka dni później. Walka o mięso dla chłopców rozgrywa się w cieniu strasznej tragedii, której rozmiary ojciec - i nie tylko on - doskonale rozumie. W pewnej chwili pojawia się na ekranie głuchy Karol Kowarzyk i tłukąc w swój bęben, ogłasza decyzję władz mszczących się za śmierć Heydricha. Lidice? Cała wieś? - woła przerażony ojciec. Mężczyzn rozstrzelali, kobiety wzięli do obozu, a dzieci na germanizacje licho wie dokąd - mówi Proszek. Sprawa wsi Lidice (potem także wsi Leżaki) była odwetem za zamordowanie Heydricha. Pacyfikacja zrównała wieś z ziemią. Spalono budynki, wyrwano z korzeniami drzewa, powyciągano z grobów zwłoki zmarłych. Po wsi Lidice miał zniknąć wszelki ślad.

13 Rosa Sala Rose, Krytyczny słownik mitów i symboli nazizmu, tłum. Zuzanna Jakubowska, Agnieszka Rurarz, Wyd. Sic!, Warszawa 2006, s. 264-265. 
Na wieść o tym, co się wydarzyło, ojciec podejmuje ostateczną decyzję. Chłopcy potrzebują mięsa, dlatego on musi zapolować na sarny. Potrzebuje mięsa dla moich chłopców. Jeśli nie przetrzymaja, będzie to i moja wina - mówi zrozpaczony do Proszka. Nie mam mięsa - odpowiada mu tamten. - Musiałbym zabić krowę. Ale jeśli chcesz, to ją zabiję. Obaj widzą jadące w oddali niemieckie ciężarówki, zapewne pełne żołnierzy. Przynieś mi kozła - prosi ojciec. - Mówiłeś, że ich mięso ma w sobie szczególna siłę. - A ty mówiłeś, że zabić tak piękne zwierze to jak zabić człowieka - odpowiada Proszek. - Odkad sa tu Szkopy, nie polowałem na nie. Karza za to śmiercia cała rodzine - dodaje. Ojciec nie daje za wygraną. Prosi o Holana, psa-myśliwego.

W opowiadaniu Smierć pięknych saren (które jest częścią większej całości pod takim tytułem) narrator nie wspomina o Lidicach. Ale kilka stron dalej w opowiadaniu Karpie dla Wermachtu (historia, która jest w nim opisana, kradzieży karpi ze stawu, w filmie - jak wspominałam - znajduje się wcześniej) mamy taki oto fragment:

\begin{abstract}
Okupacja wszędzie była zła, ale w Busztegradzie jeszcze odrobine gorsza. Zagłada Lidic wstrząsnęta catym światem. Ale Busztegrad, mój tatuś, mamusia, bracia, ja, my wszyscy widzieliśmy, jak Lidice płonęty, my styszeliśmy, jak Lidice krzyczaty zza wzgórza; chodziłem do szkoty z chtopcem o nazwisku Przygoda, i teraz jego miejsce ziało straszliwa pustka [...]. A mamusia, drobniutka, jasnowłosa, musiała chodzić pracować na lidickie pola i często wracała zapłakana, bo na grobach $z$ krwi $i$ ciat pomordowanych rosła wysoka gęsta trawa. My o zagładzie Lidic nigdy nie zdołamy zapomnieć, wgryzły się nam w serca jak kleszcz w skórę, kleszcz, który zamiast ząbków i odnóży ma czarna swastykę. Tatusia to całkowicie zmogło, miał już w oczach ten przeklęty stuletni smutek ${ }^{14}$.
\end{abstract}

Busztegrad, miejsce, w którym rodzina Oty Pavla spędziła wojnę, znajdował się niedaleko Lidic, a wywózka Hugona i Jurka odbyła się już po pacyfikacji (zresztą lidickie dzieci, pierwotnie przeznaczone do sierocińców, zagazowano w obozach). W filmie ten aspekt jest ledwo zaznaczony (choć dla czeskiego odbiorcy zapewne bardzo czytelny), ale Dušan Hamšík, pisarz-historyk zajmujący się przecież sprawą zamachu na Heydricha, rozumiał wagę osobistego doświadczenia Pavla, które tak mocno podkreśla w tekście.

Zdesperowany ojciec, chcąc upolować kozła, zabiera ze sobą Holana. Nieufny pies nie chce z nim iść. Nie reaguje ani na prośby, ani na groźby. Człowiek patrzy na psa, pies - wyczekując - na człowieka. Długi fragment montowany ujęciem-kontrujęciem. Głos z off-u komentuje: Długo patrzyli sobie w oczy. Co w nich zobaczyli, nikt się już nie dowie, bo obaj nie żyją. Zreszta

14 Ota Pavel, Śmierć pięknych saren..., s. 61-62. 
nie zdawali sobie sprawy z tego, co widza. Pewnie jeden przeklinał los psi, a drugi $\dot{z}$ dowski - i to chyba wszystko.

Losy rodziny Pavlów (właściwie Popperów) kończą się w filmie na wywózce chłopców do obozu. W książce wspomnienia sięgają do czasów powojennych. Ale Ota Pavel nie napisał w nich wielu rzeczy. Opisał je w tekstach, które po śmierci odnaleziono wśród jego zapisków. Jak tata przemierzał Afrykę to książka wydana już po upadku komunizmu, w 1994 r. Bohaterem niektórych opowiadań wchodzących w jej skład jest - co oczywiste - ojciec. Te opowiadania nie dotyczą już wojny. Dzieją się albo przed nią, albo po niej. W jednym $\mathrm{z}$ nich, zatytułowanym Bieg przez Prage, Pavel pisze:

Kiedy po wojnie komuniści stali się jedną z wiodących partii, mój tato natychmiast do niej wstąpił. Pociągnął za sobą mamę, braci. Tylko ja byłem jeszcze na to za młody. Wstąpił do partii komunistów zachwycony, jak wielu innych, Armią Czerwoną. Tego zachwytu doznał na furze, którą wiózł go z Busztiehradu zarośnięty radziecki żołnierz. Prócz tego tato wierzył, że wreszcie przyszli ci, którzy nie będą dzielić ludzi na białych i nie, Żydów i nie-Żydów. Przynajmniej tak wszyscy w swoich książkach obiecywali, od Lenina począwszy ${ }^{15}$.

Miłość taty do komunizmu skończyła się w 1951 r. wraz ze sprawą Rudolfa Slánskiego. Wówczas wewnątrz czechosłowackiej partii komunistycznej doszło do rozgrywek. Jednego z jej głównych działaczy, Slánskiego, oskarżono o imperialistyczne sympatie i skazano w procesie pokazowym. Analogicznie do sowieckiej kampanii antykosmopolitycznej, w której głównymi oskarżonymi byli Żydzi, Slánskiemu i innym sądzonym działaczom zaczęto głośno wypominać żydowskie pochodzenie (Slánský został stracony w roku 1952).

Tato siedział w kalesonach przy stole i płakał. Włosy opadły mu na czoło, a łzy kapały na gazetę. To było „Rudé Právo”, które prenumerował [...]. Obejmując go, spojrzałem ponad jego głową do tego „Rudego Práva”, gdzie podkreślił czerwonym długopisem: Rudolf Slánský, pochodzenia żydowskiego, Bedřich Geminder, pochodzenia żydowskiego [...]. Ta lista Żydów ciągnęła się dalej i była rozmazana łzami. [...] Potem wstał, uderzył w to „Rudé Právo” i krzyczał: „Ja wybaczam morderstwa. Nawet sądowe. Nawet polityczne. Ale w tej gazecie nie wolno im było napisać - pochodzenie żydowskie! Komuniści dzielą ludzi na Żydów i nie-Żydów!"16.

15 Ota Pavel, Jak tata przemierzał Afrykę, przeł. Urszula Lisowska, Jan Stachowski, Wyd. Literackie, Kraków 2004, s. 45.

16 Tamże, s. 59-60. 
Historia rodziny Popperów miała więc smutny finał - zarówno w literaturze, jak i w życiu. Ota pracował już wtedy jako dziennikarz sportowy. Kiedy odwiedził ojca-niedawnego komunistę, dostrzegł w jego oczach rozpacz. „Odbijało się w nich przeraźliwe rozczarowanie, poczucie beznadziei i rozpacz człowieka, który chciał przejść po stabilnym moście na drugą stronę rzeki, a tego mostu w rzeczywistości nie ma. W jego oczach dyndali też na sznurze Slánský z Margoliusem ${ }^{\prime 17}$. Ojciec dożył swoich dni w odosobnieniu, ale jego najmłodszy syn zobaczył diabła w austriackich górach. Tego Karel Kachynia w swoim filmie oczywiście nie pokazuje. Ten film - czasem zabawny, a czasem smutny - kończy się obrazem chłopców idących z walizkami do niemieckiego transportu i obrazem ojca, który patrzy za nimi oczami odbijającymi "ten przeklęty stuletni smutek". Jest to jednak wystarczająco przejmujące.

17 Tamże, s. 61-62. 